\title{
Clinical Characteristics of COVID-19 among Children in Sarajevo, Bosnia and Herzegovina
}

\author{
Mirela Lisičić-Konaković, Amela Kulašević, Aida Lokvančić-Bekto \\ Pediatrics Department, Ilidža Health Center, The Public Institution Health Centre of Sarajevo Canton, Sarajevo, Bosnia and \\ Herzegovina
}

Correspondence: m.konakovic@gmail.com; Tel.: + 38761710 295, Fax.: 0038733773633

Received: July 21, 2021; Accepted: September 6, 2021

\begin{abstract}
Objective - To present the characteristics of children with coronavirus disease 2019 (COVID-19) treated at the Pediatrics Department, Ilidža Primary Health Care, The Public Institution Health Centre of Sarajevo Canton, Bosnia and Herzegovina. Methods - This is a descriptive cross-sectional study of 56 children with confirmed SARS-CoV-2 infection between March 2020 - May 2021. The parameters included were: aged 0-6 years, gender, clinical signs and symptoms, type of transmission, the presence of comorbidities, vaccination with Bacillus Calmette - Guérin (BCG) vaccine, laboratory and radiology results, and treatment. Results - Out of a total of children $57.1 \%$ were aged $3-6$ years. There were $58.9 \%$ boys and $41.1 \%$ girls, 36 children had symptoms and 20 were asymptomatic. The most common symptoms were fever $(57.1 \%)$ and cough $(35.7 \%) .44$ children had a mild form of the disease and they were treated at home with counseling by a pediatrician over the phone, 10 children required outpatient treatment by a pediatrician, 2 were hospitalized. After treatment, all of them recovered. Most of the children (83.9\%) were infected by transmission from a household member. Conclusions - COVID-19 in children is generally a mild disease. Children with SARS-CoV-2 were mostly infected by contact with an adult, and transmission from children is minimal. Most children were treated symptomatically at home, only a small number were hospitalized.
\end{abstract}

Key Words: Children • Coronavirus Disease (COVID-19) - SARS-CoV-2 • Primary Health Care.

\section{Introduction}

In December 2019 the severe acute respiratory syndrome coronavirus 2 (SARS-CoV-2) was identified in Wuhan City in China. The high transmission efficiency of SARS-CoV-2 enabled the rapid spread of COVID-19 worldwide $(1,2)$. The first case of confirmed infection in a child in Bosnia and Herzegovina was at the beginning of March 2020 (3). Children have a lower susceptibility to infection and a milder form of the disease compared to adults $(4,5,6)$. The reason for this is their different immune response to the virus, less comorbidity and different ACE2 expression in children $(7,8)$.

The aims of this study were to present the characteristics of children with COVID-19 in Ilidža municipality in Sarajevo Canton, Bosnia and Herzegovina $(\mathrm{B} \& \mathrm{H})$, and to compare data with other published studies.

\section{Methods}

\section{Study Design}

This descriptive cross-sectional study was conducted at the Pediatrics Department Ilidža Primary Health Center, The Public Institution Health Centre of Sarajevo Canton, B\&H, in the period between March 2020-May 2021.

\section{Patients and Procedure}

The Pediatrics Department of Ilidža PHC has 4600 medical records of children who live in the Ilidža 
municipality and in case of need they are users of public health care. Out of the total number of children, $456(9.91 \%)$ were in quarantine due to SARS-CoV-2 infection or contact with infected persons (data obtained through COVID-19 tracking system in the department). Parents contacted a pediatrician by phone. We used the community supervision system and telemedicine guidance. Not all of the 456 children were tested, but only children with symptoms, children with a chronic disease or comorbidities, and children who went to kindergarten. 56 children had SARS-CoV-2 infection, confirmed by a positive reverse transcription-polymerase chain reaction (RT-PCR) test or positive rapid antigen diagnostic test (RDT) of a specimen, using a nasopharyngeal or oropharyngeal swab. The total sensitivity of RDT strongly depends on the RNA viral copies per milliliter of sample. RDT is a valuable addition to RT-PCR testing, as it reliably detects infectious persons with high viral loads before RT-PCR results are available (9). A special template was created for this research. The medical records of 56 children with confirmed SARS-CoV-2 infection were analyzed. The parameters included were: age (0-6 years), gender, clinical signs and symptoms, type of transmission, the presence of comorbidities, vaccination with BCG vaccine, laboratory and radiology findings, and treatment. The severity of COVID-19 was defined as mild, moderate, severe or critical on the basis of the clinical features, laboratory findings, and chest radiograph imaging, including asymptomatic infection (10). Children with asymptomatic infection had positive test results without any symptoms. Mild infection presented with milder symptoms of the respiratory or gastrointestinal system. Children with moderate infection had clinical and radiological signs of viral bronchitis or pneumonia. Severe infection presented with respiratory distress, tachypnea, hypoxemia. Some had only gastrointestinal symptoms. Children with critical infection may progress to acute respiratory distress syndrome (ARDS), or multiorgan failure, where organ dysfunction can be life-threatening $(5,10)$.

\section{Ethics Statement}

The study was approved by the Ethics Committee of Public Institution Health Centers of Sarajevo Canton, No.: 01-06-7730-3/20.

\section{Statistical Analyses}

Standard descriptive statistical methods were used in data analysis. The Chi-square $\left(\chi^{2}\right)$ test was used to determine a statistically significant difference. The level of statistical significance was $\mathrm{P}<0.05$.

\section{Results}

In the total of 56 children, $32(57.1 \%)$ were aged 3-6 years old, 15 (26.8\%) aged $1-3$ years, $6(10.7 \%)$ aged 6-12 months, 1 (1.8\%) aged 3-6 months, and $2(3.6 \%)$ aged $0-3$ months old. There were 33 $(58.9 \%)$ boys and $23(41.1 \%)$ girls (Table 1$)$.

\begin{tabular}{|c|c|}
\hline \multirow{2}{*}{ Characteristics of the children } & Children $(\mathrm{N}=56)$ \\
\hline & $\mathrm{N}(\%)$ \\
\hline \multicolumn{2}{|l|}{ Age } \\
\hline $0-3 \mathrm{~m}$ & $2(3.6)$ \\
\hline $3-6 \mathrm{~m}$ & $1(1.8)$ \\
\hline $6-12 \mathrm{~m}$ & $6(10.7)$ \\
\hline $1-3 y$ & $15(26.8)$ \\
\hline $3-6 y$ & $32(57.1)$ \\
\hline \multicolumn{2}{|l|}{ Gender } \\
\hline Male & $33(58.9)$ \\
\hline Female & $23(41.1)$ \\
\hline \multicolumn{2}{|l|}{ Symptoms } \\
\hline Fever & $32(57.1)$ \\
\hline $37^{\circ} \mathrm{C}-38^{\circ} \mathrm{C}$ & $22(68.8)$ \\
\hline $38^{\circ} \mathrm{C}-39^{\circ} \mathrm{C}$ & $9(28.1)$ \\
\hline$>39^{\circ} \mathrm{C}$ & $1(3.1)$ \\
\hline Lasted 1 - 2 days & $22(68.8)$ \\
\hline Lasted 2 - 4 days & $8(25.0)$ \\
\hline Lasted $>4$ days & $2(6.3)$ \\
\hline Cough & $20(35.7)$ \\
\hline
\end{tabular}




\begin{tabular}{ll}
\hline \multirow{2}{*}{ Characteristics of the children } & Children $(\mathrm{N}=56)$ \\
\cline { 2 - 2 } & $\mathrm{N}(\%)$ \\
\hline Stuffy nose & $10(17.9)$ \\
\hline Fatigue, Weakness & $4(7.1)$ \\
\hline Decreased appetite & $4(7.1)$ \\
\hline Runny nose & $3(5.4)$ \\
\hline Sore throat & $2(3.6$ \\
\hline Diarrhea & $2(3.6)$ \\
\hline Vomiting & $1(1.8)$ \\
\hline Rash & $1(1.8)$ \\
\hline Conjunctivitis & $1(1.8)$ \\
\hline
\end{tabular}

Of all the confirmed cases, 36 (64.3\%) children had symptoms, and 20 were asymptomatic (35.7\%). The most common symptoms were fever
$32(57.1 \%)$ and cough $20(35.7 \%)$. The fever was mild, mostly lasting up to two days. There was no significant difference in the clinical manifestations by gender $\left(\chi^{2}=0.0035 . \mathrm{P}=0.952\right) .44(78.6 \%)$ children had a mild form of the disease and they were treated at home through the community supervising system and tele-medicine guidance. Only 2 children were hospitalized. Ten (17.9\%) children had pediatric and outpatient treatment (Table 2).

The children that were treated by a pediatrician had a moderate form of the disease with multiple symptoms (fever lasting for more than 3 days, persistent cough, vomiting, rash, general weakness). Laboratory and chest X-ray (CXR) findings were mostly without deviation. Patient 2 (Table 2) had a macular rash on the lower legs and a slightly reduced number of platelets (PLT $122 \times 109 / \mathrm{L}$ ),

Table 2. Characteristics of the 10 Children with Outpatient Treatment

\begin{tabular}{|c|c|c|c|c|c|c|}
\hline Patient & Symptoms & Comorbidities & Transmission & $\begin{array}{l}\text { Laboratory } \\
\text { findings }\end{array}$ & Chest X-ray & Treatment \\
\hline \multicolumn{7}{|c|}{$6-12$ months } \\
\hline $\begin{array}{l}\text { P1; } \\
\text { Male }\end{array}$ & $\begin{array}{l}\text { Fever up to } 2 \text { days }<38^{\circ} \mathrm{C} \\
\text { Diarrhea; Decreased appetite }\end{array}$ & - & $\begin{array}{l}\text { From } \\
\text { adult person }\end{array}$ & Normal & - & $\begin{array}{l}\text { Symptomatic } \\
\text { treatment }\end{array}$ \\
\hline \multicolumn{7}{|c|}{$1-3$ years } \\
\hline $\begin{array}{l}\text { P2; } \\
\text { Female }\end{array}$ & Rash & - & $\begin{array}{l}\text { From } \\
\text { adult person }\end{array}$ & $\begin{array}{l}\text { PLT } 122 \times 109 / \mathrm{L} \\
\text { AST } 110 \mathrm{U} / \mathrm{L} \\
\text { ALT } 70 \mathrm{U} / \mathrm{L}\end{array}$ & - & $\begin{array}{l}\text { Symptomatic } \\
\text { treatment }\end{array}$ \\
\hline $\begin{array}{l}\text { P3; } \\
\text { Male }\end{array}$ & $\begin{array}{l}\text { Fever } 2-4 \text { days, } 38-39^{\circ} \mathrm{C} \\
\text { Cough }\end{array}$ & - & $\begin{array}{l}\text { From } \\
\text { adult person }\end{array}$ & Normal & - & $\begin{array}{l}\text { Symptomatic } \\
\text { treatment }\end{array}$ \\
\hline $\begin{array}{l}\text { P4; } \\
\text { Female }\end{array}$ & $\begin{array}{l}\text { Fever } 2-4 \text { days }>39^{\circ} \mathrm{C} \\
\text { Cough; Runny nose; Sore } \\
\text { throat; Fatigue; Weakness }\end{array}$ & - & $\begin{array}{l}\text { From } \\
\text { adult person }\end{array}$ & Normal & - & $\begin{array}{l}\text { Symptomatic } \\
\text { treatment }\end{array}$ \\
\hline $\begin{array}{l}\text { P5; } \\
\text { Male }\end{array}$ & $\begin{array}{l}\text { Fever up to } 2 \text { days }<38^{\circ} \mathrm{C} \\
\text { Cough; Conjunctivitis }\end{array}$ & - & $\begin{array}{l}\text { From } \\
\text { adult person }\end{array}$ & Normal & - & $\begin{array}{l}\text { Symptomatic } \\
\text { treatment }\end{array}$ \\
\hline $\begin{array}{l}\text { P6; } \\
\text { Male }\end{array}$ & $\begin{array}{l}\text { Fever up to } 2 \text { days }<38^{\circ} \mathrm{C} \\
\text { Cough; Runny nose }\end{array}$ & - & $\begin{array}{l}\text { From } \\
\text { adult person }\end{array}$ & Normal & - & $\begin{array}{l}\text { Symptomatic } \\
\text { treatment }\end{array}$ \\
\hline \multicolumn{7}{|c|}{$3-6$ years } \\
\hline $\begin{array}{l}\text { P7; } \\
\text { Male }\end{array}$ & $\begin{array}{l}\text { Cough; A stuffy nose } \\
\text { Decreased appetite }\end{array}$ & Chronic bronchitis & $\begin{array}{l}\text { From } \\
\text { adult person }\end{array}$ & Normal & $\begin{array}{l}\text { Suggestive } \\
\text { of bronchitis }\end{array}$ & $\begin{array}{l}\text { Azithromycin; } \\
\text { Salbutamol/3 days }\end{array}$ \\
\hline $\begin{array}{l}\text { P8; } \\
\text { Male }\end{array}$ & Fever $2-4$ days $38-39^{\circ} \mathrm{C}$ & - & $\begin{array}{l}\text { From } \\
\text { adult person }\end{array}$ & $\begin{array}{l}\text { L } 2.5 \times 109 / \mathrm{L} \\
\text { Ly } 49 \times 109 / \mathrm{L} \\
\text { Ne } 35 \times 109 / \mathrm{L}\end{array}$ & - & $\begin{array}{l}\text { Symptomatic } \\
\text { treatment }\end{array}$ \\
\hline $\begin{array}{l}\text { P9; } \\
\text { Male }\end{array}$ & Fever $2-4$ days $38-39^{\circ} \mathrm{C}$ & - & Unknown & Normal & Normal & $\begin{array}{l}\text { Symptomatic } \\
\text { treatment }\end{array}$ \\
\hline $\begin{array}{l}\text { P10; } \\
\text { Female }\end{array}$ & $\begin{array}{l}\text { Fever } 2-4 \text { days }<38^{\circ} \mathrm{C} \\
\text { Cough; Sore throat }\end{array}$ & $\begin{array}{l}\text { Hypothyroidism; } \\
\text { Chronic Bronchitis } \\
\text { Obesity }\end{array}$ & $\begin{array}{l}\text { From } \\
\text { adult person }\end{array}$ & Normal & - & $\begin{array}{l}\text { Symptomatic } \\
\text { treatment }\end{array}$ \\
\hline
\end{tabular}


which returned to normal after three days of treatment with vitamins. Patient 8 (Table 2) had a fever up to $39^{\circ} \mathrm{C}$ that lasted five days, with leukopenia (WBC $2.5 \times 109 / \mathrm{L}$ ), which returned to normal after the fifth day, without special treatment. Two infants, one with fever, diarrhea and vomiting, and the other with prolonged fever and symptoms of bronchiolitis, were hospitalized. Eleven children had comorbidities including: atrial septal defect, chronic bronchitis, vesicoureteral reflux, hypothyroidism, and obesity. In our study, these comorbidities did not affect the severity of the disease. Most children, 47 (83.9\%), were infected by a household member. Seven children $(12.5 \%)$ were infected in kindergarten from another child, while for $2(3.6 \%)$ children the type of transmission was unknown. All the children, except one child, had received the BCG vaccine when they were born, Table 3 .

Table 3. Characteristics of 56 Children with COVID-19 Included in the Study

\begin{tabular}{ll}
\hline \multirow{2}{*}{ Characteristics of the children } & Children (N=56) \\
\cline { 2 - 2 } BCG vaccinated at birth & $\mathrm{N}(\%)$ \\
\hline Presence of comorbidities & $55(98.2)$ \\
\hline Comorbidities & $11(19.6)$ \\
\hline Cardiovascular & $4(36)$ \\
\hline Urogenital & $3(27)$ \\
\hline Prematurity & $2(18)$ \\
\hline Respiratory & $2(18)$ \\
\hline Gastrointestinal & $1(9)$ \\
\hline Endocrine & $1(9)$ \\
\hline Obesity & $1(9)$ \\
\hline Neurological & $1(9)$ \\
\hline Atopic constitution & $1(9)$ \\
\hline Transmission & $2(3.6)$ \\
\hline $\begin{array}{l}\text { From a sick parent or household } \\
\text { member }\end{array}$ & $47(83.9)$ \\
\hline From child- kindergarten & $7(12.5)$ \\
\hline Unknown & \\
\hline
\end{tabular}

\begin{tabular}{ll}
\hline \multirow{2}{*}{ Characteristics of the children } & Children (N=56) \\
\cline { 2 - 2 } Symptoms & $\mathrm{N}(\%)$ \\
\hline Symptomatic & $36(64.3)$ \\
\hline Asymptomatic & $20(35.7)$ \\
\hline Place of treatment & \\
\hline Home treatment & $44(78.6)$ \\
\hline Outpatient treatment & $10(17.9)$ \\
\hline Hospital treatment & $2(3.6)$ \\
\hline LAB Test performed & $12(21.4)$ \\
\hline Chest X ray performed & $3(5.4)$ \\
\hline
\end{tabular}

\section{Discussion}

Children with COVID-19 have a wide spectrum of clinical manifestations. During the pandemic, children are less represented in relation to the total number of patients and have a milder form of the disease compared to adults $(6,11)$. The Chinese Center for Disease Control (CDC) revealed that less than $1 \%$ of cases occurred in children aged less than 10 years (12). In the United States, children $<18$ years account for approximately $13 \%$. The incidence increases with increasing age $(13,14,15)$. In this study, over 14 months from a total of 4600 children, 56 (1.2\%) had COVID-19. The majority of children $(35.7 \%)$ in our study were asymptomatic, $78.6 \%$ children had a mild form of the disease, $3.6 \%$ children had a moderate form of the disease (all under 1 year of age). Data from the United States (14) and systematic review and meta-analysis by Irfan et al. (16) showed that hospitalization was most common among pediatric patients aged $<1$ year and those with a chronic disease. Our study was without lethal outcomes. A systematic review by Viner et al. (17) that included children $<20$ years of age, documented that the proportion of asymptomatic infections ranged from 15 to $42 \%(4,16)$. We observed slightly more boys than girls. There was no significant difference in the clinical manifestations of the disease by gender $(5,6)$. In our study, the most common symptoms were fever $(57.1 \%)$ and cough $(35.7 \%)$. Other studies also reported 
cough and fever as the most common symptoms (4, 16). Gastrointestinal symptoms may occur without respiratory symptoms (18). In our study $1.8 \%$ of the children had vomiting and $3.6 \%$ diarrhea. Cardiovascular abnormalities (heart failure, arrhythmias, myocarditis, pericarditis, cardiogenic shock, pulmonary embolism) have been reported in smaller case series (19), but in our study we did not have any of these. In our report, skin rash presented in only $1.8 \%$ children. Cutaneous manifestations have been rarely reported, and it is not clear whether the cutaneous manifestations were due to SARS-CoV-2 infection itself or were a therapeutic outcome (20). Leukopenia and thrombocytopenia were also reported $(21,22)$. In our study, leukopenia and thrombocytopenia were reported in $1.8 \%$ children.

In our report, $17.9 \%$ of the children who had prolonged fever ( $>3$ days) or cough that made breathing difficult, and bad general condition, were examined by a pediatrician on an outpatient basis. The treatment was symptomatic: vitamins, hydration, antipyretics and home isolation for 2 weeks. This is the general clinical management for treatment that was prescribed for patients in the community (10). Only one case, patient 7 (Table 2) with chronic bronchitis was treated with an antibiotic, Azithromycin. Chest imaging is not routinely necessary for diagnosis of COVID-19 in children (23). We performed chest imaging in 5.4\% cases; one was normal and two suggestive of bronchitis. Most of the children $(83.9 \%)$ were infected by transmission from a sick parent or household member. Initial studies indicated that children were asymptomatic carriers, resulting in the closure of kindergartens and schools $(24,25)$. Recent data suggest that children with SARS-CoV-2 acquire their infection from contact with an adult, with minimal secondary transmission from children (26, 27). In our study, $98.2 \%$ children had received the BCG vaccine, according to the protocol after birth. An increasing number of studies have described the nonspecific protective effects against diseases after immunization with an unrelated vaccine or microbial antigen. Published studies suggest that the population from the regions where BCG vaccination is performed had a milder clinical form of COVID-19 $(28,29)$.

Despite the fact that children with COVID-19 most often have a mild disease, there are studies presenting unexpected response to the infection $(30,31)$. Our report included a small number of children from the Sarajevo Canton but covered all cases in the Ilidža municipality, and this data can contribute to an understanding of COVID-19 among children in $\mathrm{B} \& \mathrm{H}$.

\section{Conclusions}

On the basis of the current data, we can conclude that COVID-19 in children is most often a mild disease, with no significant gender difference. Children with SARS-CoV-2 were infected mostly by contact with an adult, and transmission from children is minimal. Most children were treated symptomatically at home. A small number of children were hospitalized.

Authors' Contributions: Conception and design: ALB and MLK; Acquisition, analysis and interpretation of data: AK and MLK; Drafting the article: MLK; Revising it critically for important intellectual content: ALB, AK and MLK; Approved final version of the manuscript: ALB, AK and MLK.

Conflicts of Interest: We declare that we have no conflict of interest.

\section{References}

1. Zhu N, Zhang D, Wang W, Li X, Yang B, Song J, et al. China Novel Coronavirus Investigating and Research Team. A Novel Coronavirus from Patients with Pneumonia in China, 2019. N Engl J Med. 2020;382(8):727-33.

2. Yang Y, Peng F, Wang R, Yange M, Guan K, Jiang T, et al. The deadly coronaviruses: The 2003 SARS pandemic and the 2020 novel coronavirus epidemic in China. J Autoimmun. 2020;111:102487.

3. Arapović J, Skočibušić $S$. The first two months of the COVID-19 pandemic in Bosnia and Herzegovina: Singlecenter experience. Bosn J Basic Med Sci. 2020;20(3):396400.

4. Lu X, Zhang L, Du H, Zhang J, Li YY, Qu J, et al. Chinese Pediatric Novel Coronavirus Study Team. SARS-CoV-2 Infection in Children. N Engl J Med. 2020;382(17):1663-5. 
5. Dong Y, Mo X, Hu Y, Qi X, Jiang F, Jiang Z, et al. Epidemiology of COVID-19 Among Children in China. Pediatrics. 2020;145(6):20200702.

6. Guan WJ, Ni ZY, Hu Y, Liang WH, Ou CQ, He JX, et al. China Medical Treatment Expert Group for Covid-19. Clinical Characteristics of Coronavirus Disease 2019 in China. N Engl J Med. 2020;382(18):1708-20.

7. Yan R, Zhang Y, Li Y, Xia L, Guo Y, Zhou Q. Structural basis for the recognition of SARS-CoV-2 by full-length human ACE2. Science. 2020;367(6485):1444-8.

8. Hoffmann M, Kleine-Weber H, Schroeder S, Krüger N, Herrler T, Erichsen S, et al. SARS-CoV-2 Cell Entry Depends on ACE2 and TMPRSS2 and Is Blocked by a Clinically Proven Protease Inhibitor. Cell. 2020;181(2):271-80.

9. Wagenhäuser I, Knies K, Rauschenberger V, Eisenmann $\mathrm{M}, \mathrm{McDonogh} \mathrm{M}$, Petri N, et al. Clinical performance evaluation of SARS-CoV-2 rapid antigen testing in point of care usage in comparison to RT-qPCR. EBioMedicine. 2021;26:69:103455.

10. Fang F, Chen Y, Zhao D, Liu T, Huang Y, Qiu L, et al. Chinese Pediatric Society and the Editorial Committee of the Chinese Journal of Pediatrics. Recommendations for the Diagnosis, Prevention, and Control of Coronavirus Disease-19 in Children-The Chinese Perspectives. Front Pediatr. 2020;8:553394.

11. Zare-Zardini H, Soltaninejad H, Ferdosian F, Hamidieh AA, Memarpoor-Yazdi M. Coronavirus Disease 2019 (COVID-19) in Children: Prevalence, Diagnosis, Clinical Symptoms, and Treatment. Int J Gen Med. 2020;13:477-82.

12. Wu Z, McGoogan JM. Characteristics of and Important Lessons From the Coronavirus Disease 2019 (COVID-19) Outbreak in China: Summary of a Report of 72314 Cases From the Chinese Center for Disease Control and Prevention. JAMA. 2020.7;323(13):1239-42.

13. Leidman E, Duca LM, Omura JD, Proia K, Stephens JW, Sauber-Schatz EK. COVID-19 Trends Among Persons Aged 0-24 Years - United States, March 1-December 12, 2020. MMWR Morb Mortal Wkly Rep. 2021;70(3):8894.

14. Bialek S, Gierke R, Hughes M, McNamara LA, Pilishvili T, SkoffT, CDC COVID-19 Response Team. Coronavirus disease 2019 in children - United States, 2020. MMWR Morb Mortal Wkly Rep. 2020;69: 422-6.

15. Livingston E, Bucher K. Coronavirus Disease 2019 (COVID-19) in Italy. JAMA. 2020;323(14):1335.

16. Irfan O, Muttalib F, Tang K, Jiang L, Lassi ZS, Bhutta Z. Clinical characteristics, treatment and outcomes of paediatric COVID-19: a systematic review and meta-analysis. Arch Dis Child. 2021;106(5):440-8.
17. Viner RM, Ward JL, Hudson LD, Ashe M, Patel SV, Hargreaves $\mathrm{D}$, et al. Systematic review of reviews of symptoms and signs of COVID-19 in children and adolescents. Arch Dis Child. 2020:320972.

18. Tian Y, Rong L, Nian W, He Y. Review article: gastrointestinal features in COVID-19 and the possibility of faecal transmission. Aliment Pharmacol Ther. 2020;51(9):843-51.

19. Wu L, O'Kane AM, Peng H, Bi Y, Motriuk-Smith D, Ren J. SARS-CoV-2 and cardiovascular complications: From molecular mechanisms to pharmaceutical management. Biochem Pharmacol. 2020;178:114114.

20. Galván Casas C, Català A, Carretero Hernández G, Rodríguez-Jiménez P, Fernández-Nieto D, Rodríguez-Villa Lario A, et al. Classification of the cutaneous manifestations of COVID-19: a rapid prospective nationwide consensus study in Spain with 375 cases. Br J Dermatol. 2020;183(1):71-7.

21. Henry BM, Lippi G, Plebani M. Laboratory abnormalities in children with novel coronavirus disease 2019. Clin Chem Lab Med. 2020;58(7):1135-8.

22. Zimmermann P, Curtis N. COVID-19 in Children, Pregnancy and Neonates: A Review of Epidemiologic and Clinical Features. Pediatr Infect Dis J. 2020;39(6):469-77.

23. Raissaki M, Shelmerdine SC, Damasio MB, Toso S, Kvist O, Lovrenski J, et al. Management strategies for children with COVID-19: ESPR practical recommendations. Pediatr Radiol. 2020 Aug;50(9):1313-23.

24. Bayham J, Fenichel EP. Impact of school closures for COVID-19 on the US health-care workforce and net mortality: a modelling study. Lancet Public Health. 2020;5(5):271-8.

25. Van Lancker W, Parolin Z. COVID-19, school closures, and child poverty: a social crisis in the making. Lancet Public Health. 2020;5(5):243-4.

26. Viner RM, Russell SJ, Croker H, Packer J, Ward J, Stansfield C, et al. School closure and management practices during coronavirus outbreaks including COVID-19: a rapid systematic review. Lancet Child Adolesc Health. 2020;4(5):397-404.

27. Hildenwall H, Luthander J, Rhedin S, Hertting O, Olsson-Åkefeldt S, Melén E, et al. Paediatric COVID-19 admissions in a region with open schools during the two first months of the pandemic. Acta Paediatr. 2020;109(10):2152-4.

28. Sohrabi Y, Dos Santos JC, Dorenkamp M, Findeisen H, Godfrey R, Netea MG, et al. Trained immunity as a novel approach against COVID-19 with a focus on Bacillus Calmette-Guérin vaccine: mechanisms, challenges and perspectives. Clin Transl Immunology. 2020;9(12):1228. 
29. Escobar LE, Molina-Cruz A, Barillas-Mury C. BCG vaccine protection from severe coronavirus disease 2019 (COVID-19). Proc Natl Acad Sci USA. 2020;117:17720-6.

30. Sporišević L, Mesihović-Dinarević S, Jogunčić A, Pilav A. "Coronavirus Disease 2019 (COVID-19): A New Pediatric Challenge”. Journal of Health Sciences. 2020;10(2):103-8.
31. Rowley AH. Understanding SARS-CoV-2-related multisystem inflammatory syndrome in children. Nat Rev Immunol. 2020;20(8):453-4. 